\title{
Deliberative Policy of Village Government in Village Fund Management in Jembrana Regency
}

\author{
I Putu Dharmanu Yudartha ${ }^{1 *}$, Komang Adi Sastra Wijaya ${ }^{2}$ \\ ${ }^{1}$ Department Public Administration Udayana University \\ ${ }^{2}$ Department Public Administration Udayana University \\ Email:p.dharmanu@gmail.com
}

\begin{abstract}
The village government in Jembrana Regency is a village that has not been included in the independent village category. The increasing development of village funds in each village in Jembrana Regency is an excellent opportunity in strengthening deliberative perspective policy. Village fund management maintained by deliberative approaches at the village government level is a big challenge to realize. The development of public policy theory encourages the government to formulate deliberative public policy, and the village government has room to apply the theory. This became an empirical and theoretical basis for researchers to conduct analysis related to deliberative policies in village government in village fund management. This research uses a mixed-method that combines qualitative and quantitative research to obtain more comprehensive data later. The research object in this study is in selected villages in Jembrana Regency. The findings in this study show that deliberative policy analysis, based on influence indicators, shows that each community group has been given space in influencing and making decisions in the village. The inclusion indicator shows that it has involved various figures and interest groups in the village in formulating policies through consensus deliberations. The last hand is that there is an open dialogue in mapping the problem, but policy determination must also look at the ability of the budget, especially village funds.
\end{abstract}

Keywords: deliberative, policy, village government

\section{INTRODUCTION}

Public policy in development becomes an integral part of the government's, including at the village government level. Village autonomy imposed approximately 6 (six) years provides ample space for the Village government in formulating and implementing policies in the village scope. The implementation of village autonomy seeks to encourage the creation of significant development in the village. It is reinforced by the commitment of the central and local governments in allocating funds in the form of Village funds, village fund allocation and grant funds. This condition must undoubtedly be strengthened by the Village government's ability to produce public policies that are in line with problems in the village community. Deliberative public policy becomes an ideal concept to be actualized appropriately in formulating to evaluating policies. Dynamics in setting policies in the village environment become an interesting study because of the challenges faced in determining the best choice in overcoming the problem [1]. The deliberative approach becomes the suitable means. By definition, the deliberative policy is a policy that prioritizes the process of intensive discussion between governments, citizens and interest groups. That is, every policy formulation must be communicated and involve all elements and citizens who will bear the consequences of a policy [2]

Developing village autonomy in independent villages in the policy context becomes an interesting study, especially in Bali Province. It is based on the existence of indigenous villages as part of village governance in Bali. Bali has a uniqueness that has two villages, namely traditional villages and official villages (village government). On the other hand, it becomes a challenge in synergizing policies in overcoming problems between the two types of villages that can intersect with each other. Autonomy in village service or village government refers to village law number 6 of 2014 , which regulates village authority included in policy formulation. In addition, fiscally, the village government is given village funds every year to support development in the village environment. In traditional villages, especially in Bali, also have their autonomy. It is related to the authority of the village in making the rule of law, the application of its customary law, and the authority of indigenous villages in dropping their statutes [3].

The muscularity attached to the two types of villages in Bali needs to be seen to the extent that it has a positive impact or as a result of making a deliberative 
approach policy. If you look at the development of villages in Bali, it is directly proportional to development inequality, especially in the economic field. Before the covid-19 pandemic, the development of villages in southern Bali was significant because it was in line with the high number of tourist visits. Conversely for villages in northern and western Bali tend to develop less critical. One indicator of the development of a village in the village building index divides the village development category into five categories, namely Self-sufficient Village, Advanced Village, Developing Village, Lagging Village, and Very Disadvantaged Village. One of the exciting areas in the analysis is Jembrana Regency because it has great potential in agriculture, plantations, fisheries and marine. In the pandemic period, the economic growth of Jembrana regency remains positive compared to other districts or cities in Bali, where most economic growth is negative. This condition is contrary to village development in Jembrana regency, based on data from the 2020 Building Village Index on average village development in Jembrana in the Advanced category. It should be optimized because the following are included in Bali's five other districts or cities, namely Denpasar City, Badung Regency, Tabanan Regency, Klungkung Regency and Gianyar Regency SelfSufficient category [4]. Jembrana Regency is included in the Advanced category in developing its village together with Bangli Regency and Karangasem Regency.

The increase in village development, especially in Jembrana regency, is a fascinating study to be analyzed from a deliberative policy perspective. The involvement of interest groups at the village level becomes a means of strengthening policies to fit the challenges and problems faced by the village community. In the covid-19 pandemic, there are changes in challenges and issues faced, especially health and economic issues. Therefore, the importance of each village in producing policies that have a significant impact in maintaining public health and encouraging village economic growth. The existence of village funds is one of the forces in promoting villages to produce policies, services, and activities that significantly impact the village during the covid-19 pandemic. Empirical conditions also strengthen this condition that Jembrana Regency has potential in fisheries, agriculture, plantations and the tourism sector [5].

There are several problem formulations for analyzing the problems described above. First, What is the deliberative policy of the scope of the Village government in the management of Village funds in Jembrana Regency? Second, what are the challenges or obstacles in the deliberative policy of the village government in the direction of village funds in Jembrana Regency? To strengthen this research, the authors compared previous studies to explain the new value of the study. First, 2019 it studies under the Deliberative Process in deliberative for Poverty Alleviation Policy in Surakarta. This thesis research by Lufti Untung Angga L and Agus Heruanto Hadna aims to understand the process of preparing multidimensional poverty alleviation policies in Surakarta city judging from the deliberative approach. Specifically, researchers identify (1) stakeholders involved and how their roles and interests are, and (2) stakeholder deliberative mechanisms in the process of public policy drafting. The study's findings showed that local poverty parameters managed to correct bps poverty data so that poverty data in Surakarta city doubled. It means that the definition of poverty is appropriately used by the Surakarta City Government [6]. The above research equation with research conducted by researchers is in terms of theories used deliberative public policy. The difference is from the object of study and the method used. The contribution of the above research with research that researchers will do is in strengthening theoretical studies on deliberative policies.

Second Research, with the Title of Cendana Management Policy Formulation in East Nusa Tenggara (Deliberative Policy Study Approach) by Agung Sri Raharjo, San Afri Awang, Agus Pramusinto and Ris Hadi Purwanto. Research in the form of a dissertation in the form of this 2014 dissertation aims to obtain data and evaluative explanations of the formulation process of Regional Regulation No. 25 of 2001 on Sandalwood in the perspective of deliberative policy; Formulate policy recommendations on Sandalwood that can accommodate the interests of the community and encourage an increase in regional income. The research uses a qualitative descriptive research design. The results showed that the formulation process of District Regulation No. 25 of 2001 on Sandalwood was not carried out deliberatively. The dialogue in the formulation process fails to build excellent and fair relationships, reciprocity imperfections between dialogue participants, unbalanced learning processes and weak creativity in the dialogue process. This resulted in the absence of shared identity, meaning, and new heuristic and genuine innovation during the dialogue process [7]. The above research equation with research conducted by researchers is in terms of deliberative policy theory, while the difference is related to the research object and methods used. Its contribution is more to providing a new understanding of aspects of formulation in the deliberative policy.

\section{LITERATURE REVIEW}

Policy formulation is one of the essential beginnings in producing an ideal public policy with the needs and problems faced in the village. Policy development must be able to accommodate some of the aggregation of existing interests in the village. The formulation of deliberative policies is certainly interrelated or based on deliberative democracy. Interpreting deliberative democracy in which several things are the focus, namely mandate-comprehensiveness related to issues discussed and debated, mandate-significance related to coverage in policy formulation, resources about resources owned (budget, human resources, facilities), Representativeness about the parties involved and aspirations needed in policy formulation and contestation related to the ability 
to in the process of articulate differences of opinion and argument in the deliberation process [8].

In general, it is the most democratic concept of public policy formulation because it gives the vast public space to contribute its choices to the government before decision making. The process of public policy analysis of this "deliberation" model is much different from technocratic models because of the role of policy analysis "only" as a facilitator for the public to find solutions through policy decisions [9]. This deliberative model is also known as the argumentative policy model, which is a model of policy formulation involving arguments from the parties or by studying written statements from various parties.

The deliberative policy is a derivation of deliberative democracy. Deliberative democracy is rooted in the conception of "public space" in taking decisions broadly and taking accurate decisions through deliberation rather than through voting [10]. Deliberative democracy prioritizes decision-making procedures that emphasize reflection and extracting issues through dialogue and exchange of experiences between parties and stakeholders. The goal is to reach consensus through deliberation based on the results of discussions taking into account various criteria. Public engagement is at the core of deliberative democracy related to policy planning and development [11]. Deliberative democracy is different from representative democracy, which emphasizes representation, strict suggestive election procedures, and recognizes the majority and minority of the terms. Deliberative democracy prioritizes cooperation between ideas and between parties, while the keywords of representative democracy are competition between ideas and between groups. Indicators in deliberative policy, according to Carsons and Karp in Mardiyanta [12] there are three indicators:

1. Influence: means must have the ability to influence policy and decision making;

2. Inclusion: means that the policy formulation process must represent the population and accept every diverse point of view and value, as well as provide equal opportunities for all participating parties;

3. Deliberation: means that the process must provide open dialogue, access to information, a sense of respect for differences, a space for greetings to understand and map problems and aim towards mutual agreement.

\section{METHODS}

This research uses a mixed-method that combines quantitative with qualitative better known as sequential mixed methods. According to Creswell, this method combines or expands the inventions obtained from one way with the discovery of another approach [13]. Researchers begin with quantitative methods through survey research by analyzing the public perception of the program through predetermined instruments. The survey is a type of cross-sectional, i.e. data is only collected for a particular time to describe the condition of the population. Furthermore, qualitative methods with descriptive approaches to researching subjects and research objects are based on quantitative data results. This study conducted a survey in ten villages purposive sampling and determination of respondents in each village purposively; each village selected ten respondents.

\section{RESULTS AND DISCUSSIONS}

The analysis process in this paper starts from analyzing the findings in the form of interviews with informants. Informants selected in research are certain parties who have a significant influence in the deliberative policy formulation process. The first aspect that the author asks is related to the formulation of problems in the village. Based on the interview results, the involvement of community leaders began from the level of deliberation of hamlets to villages. The role of village officials in providing space for the village community to absorb problems and aspirations. This condition generally applies the same in selected villages in this study.

The involvement of various components in the village in the formulation of policies in the village, of course, faced multiple challenges, especially in determining priority issues. The findings on the ground through interviews showed that the priority scale was determined at village deliberations, as for technicalities through participation. This happened in several villages in Jembrana Regency. In addition, the priority scale is also specified in the Regional Device Work Plan. Technically the process of determining the priority scale starts from the Village Deliberation, then continues before the village deliberations for the role of the proposed new priority to the village deliberations to be established. After determining the problem based on the scale of importance, it is necessary to see the support of the village fund. The budget in support of policies in the village is very dependent on the availability of village funds. So it can be said that village funds become an essential factor in the sustainability of a policy. This condition needs to be anticipated because the central government budget sources village funds. Therefore, it is necessary to increase village income through Village Owned Enterprises to increase finances at the village level.

The next stage is related to the implementation of policies or programs sourced from village funds. The policy implementation process is based on formulating policies based on village deliberation, then involves village and community leaders as implementers. It is reinforced by regulations ranging from planning, supervision to coordination in policy implementation. The role of the village community, especially as the leading actor (implementer) in the village policy or 
program. The deliberative policy process has positioned the society starting from the formulation, implementation and evaluation of policies. The role of the community is not fully involved because it is associated with the vision and mission of the village head.

Minority groups certainly also need to be considered one of the policy targets, namely the involvement of the poor, women and the younger generation in conveying their aspirations. Findings on the ground show that the group's aspirations we received in deliberations in the hamlet, so already all in the village deliberation are involved there. Suppose you see or analyze the realization of policies with proposals from the community and community leaders, religions, customs, and so on. Facts on the ground show that about 50 per cent of community proposals can be realized, while proposals have not been realized. According to the author and interviews with informants, the problem faced claimed that the village can absorb almost all submissions, but for realization, it seems that not all, maybe the village funds are not enough.

Interviews with various parties in analyzing deliberative policies in Jembrana regency villages show that the process of policy formulation, especially in the management of village funds, has been running according to procedures. The author says that some things still need to be improved, especially in the situation of the covid-19 pandemic. First, it is related to the essence and target of a more sustainable policy that provides economic benefits for villagers. It gives increased village acceptance, for example, through Village Owned Enterprises (BUMDes). Second, the significant dependence on village funds needs to be a serious concern because, amid deficit, state revenues will undoubtedly substantially impact allocating village funds during a pandemic. Third, it is necessary to change the strategy in policy formulation, especially in analyzing problems in the village, such as using information technology such as websites, social media, and whatsapp to strengthen information and information openness in the village.

The authors also strengthened the analysis through quantitative data based on the spread of questionnaires to rural communities in Jembrana Regency. The authors used three indicators on Deliberative Policy based on Carsons and Karp thoughts. The first indicator is influence, i.e. various parties in the village scope must have the ability to implement policies and decision-making. It is essential to avoid dominance of power in decision making, for example, the role of the village head, which is significant in decision making. In addition, the involvement of various parties aims to create justice, equality and equitable distribution, which is in line with deliberative democracy [14].

Deliberative democracy becomes the basis in deliberative policy; to produce policies with deliberative democracy, necessary to apply deliberative democracy as a primary basis. To analyze the indicator, the author, as a researcher, asked questions to respondents. In general, concerning decision making, the author assesses the involvement of various parties, then the opportunity in proposing and deciding policies. Such as the role of indigenous villages, village health agencies, youth groups and village escorts related to involvement in decision making and decision making. The data obtained shows that most respondents agreed with an average of 76 per cent, stated quite often on average as much as 17.8 , then rarely stated with an average of 5.7 per cent and never communicated as much as 0.5 per cent. The most respondents who said they were always involved was the role of indigenous villages in making and making decisions with a percentage of 85 per cent. The data is generally good, but interviews and observations show that the role of village devices is more dominant. It is based on every policy made influenced by two dominant factors: the availability of village funds based on decisions to the village and the urgency of problems in each village.

The second indicator is Inclusion, meaning that the policy formulation process must represent the population and accept every diverse point of view and value and provide equal opportunities for all parties to participate. The author asked questions related to the policy agenda, the formulation of village fund-based habits, the implementation of village fund-based policies, and the evaluation of village fund-based policies. Of course, this involves all interest groups in the village. The survey showed that most respondents always stated with a percentage of 75.25 per cent, said quite often with an average of 22.75 per cent, rarely stated at 1.75 per cent and never stated by 0.25 per cent. The highest percentage assessment is related to formulating a policy plan proposal and input by involving interest groups in the village with a percentage of 81 per cent. The above data is also strengthened by the results of interviews and observations, where determining the policy agenda starts from deliberation at the village level to the village level. The deliberation activities involve various social groups, including poor people, women and the younger generation in the village. The policy process in the village of Jembrana regency has been able to use deliberative. However, in essence, it is still not maximal, especially in determining the scale of priorities that still depend on the availability of budgets.

The next indicator is deliberation, meaning the process must provide open dialogue, access to information, mutual respect for differences, space for mutual understanding and mapping of problems and aiming towards mutual agreement. To analyze the deliberation indicator, the author has surveyed selected responders. The author submits several statements regarding the policy's benefits to the public, policy objectives, differences of opinion; there is the openness of information and dialogue or discussion in the formulation of policy evaluation. The data obtained showed that, on average, the highest respondents always stated with a percentage of 83.4 per cent. Respondents who said quite often 12.4 per cent rarely stated as much as four per cent and never as much as 0.2 per cent. Respondents who 
stated that it was always the highest percentage, which was 86 per cent, were the statement of policy and program objectives sourced from village funds in line with the goals of the village government. Compared with the findings on the ground and observation results, the deliberative process of policy in the village is still not maximal in using information technology, especially the village website. Some village governments have not displayed informative websites, do not yet have social media and public service. Information becomes one of the essential indicators in ensuring deliberative quality [15]; if communication is only one-way, the deliberative process has not been effective. Another indicator is completeness: related to mutually reinforcing arguments in the formulation of problems. Consciousness is the existence of participating in formulating problems based on later benefits, and diversity is the extent to which the parties present represent the uniformity of the community in their region [16]. Therefore, it is necessary to synergize various interest groups in the village, then strengthened by two-way information to encourage participation and strengthen in formulating problems in the village. Deliberative policies need to be initiated by excellent communication and information. It will undoubtedly impact the openness of the dialogue process in the process of formulation and evaluation of policies later.

\section{CONCLUSION}

In general, policies in the village sphere have been able to implement deliberative ranging from policy formulation to implementation and evaluation of its policies. However, several things need to be evaluated and strengthened in deliberative approaches in the village, especially in Jembrana Regency. First, formulating and evaluating policies has not been

\section{REFERENCES}

[1] E. Winarno, "Kompleksitas proses kebijakan sosial," Media Inf. Penelit. Kesejaht. Sos., vol. 41, no. 3, pp. 256-258, 2017, [Online]. Available:

https://ejournal.kemsos.go.id/index.php/media informasi/article/download/2258/1107.

[2] W. Kumorotomo, "Kebijakan Publik Deliberatif Beberapa Prasyarat untuk Menjamin Kesejahteraan Rakyat," 2013. [Online]. Available: http://kumoro.staff.ugm.ac.id/file_artikel/Kebi jakan Publik Deliberatif.pdf.

[3] D. G. A. S. Y. Purnama and A. A. I. A. A. Dewi, "Desa adat Dalam Pengelolaan Tanah Adat Bali Berbasis Kebijakan Daerah," Acta Com., vol. 4, no. 2, p. 343, 2019, doi: 10.24843/ac.2019.v04.i02.p16.

[4] D. J. P. D. dan Perdesaan, Peringkat Indeks Desa Membangun Tahun 2021. Kementerian Desa Republik Indonesia, 2021. optimally using information technology, through websites, social media, and applications. Second, it is necessary to study or analyze problem mapping in the village so that the data and information become the basis in policymaking by involving the community. Third, high dependence on village funds in formulating policies in the village environment. The relevant advice as a form of recommendation in optimizing deliberative approaches in the village is that the Village Fund Management Policy should focus on generating added value for the community and village acceptance to produce policies that can overcome the problem broadly. Further advice, Modernization and Innovation of policy formulation based on information technology, and databased or village potential should be implemented by the village government in Jembrana Regency.

\section{AUTHORS' CONTRIBUTIONS}

As a researcher in this study, the author produced an analysis in strengthening deliberative policies in the village environment. In addition, it further emphasizes that the importance of village funds as a wheel of village development must also be anticipated so as not to make dependence on the central government. This research produces recommendations in establishing policy models and strengthening public policy in deliberative approaches.

\section{ACKNOWLEDGMENTS}

A big thank you to the rector of Udayana University and the Head of Udayana University Research and Service Institute, who has funded this research. As well as to fellow students involved in surveyors, in addition, thank you for the willingness of village officials, community leaders and village community groups in Jembrana Regency

[5] N. F. Yusuf, "Menteri BUMN inginkan Kabupaten Jembrana jadi lumbung pangan bagi Bali," ANTARA news, 2021. .

[6] L. U. Angga and A. H. Hadna, "Proses deliberatif dalam kebijakan pengentasan kemiskinan multidimensi di surakarta," Universitas Gadjah Mada, 2019.

[7] S. A. S. Raharjo, S. A. Awang, and A. Pramusinto, "Formulasi Kebijakan Pengelolaan Cendana di Nusa Tenggara Timur (Pendekatan Studi Kebijakan Deliberatif)," Universitas Gadjah Mada, 2014.

[8] M. Hurlbert and E. Andrews, "Deliberative democracy in Canadian watershed governance," Water Altern., vol. 11, no. 1, pp. 163-186, 2018.

[9] N. N. Abdullah and M. F. Abdul Rahman, "The Use of Deliberative Democracy in Public Policy Making Process," SSRN Electron. J., vol. 5, no. 3, pp. 221-230, 2017, doi: 10.2139/ssrn.2769105.

[10] V. Savic, "Integration of deliberative 
democracy and policymaking: A vision of a deliberative system," Filoz. i Drus., vol. 23, no. 4, pp. 170-189, 2012, doi: 10.2298/fid1204170s.

[11] J. Gregory, J. Hartz-Karp, and R. Watson, "Using deliberative techniques to engage the community in policy development," Aust. New Zealand Health Policy, vol. 5, pp. 1-9, 2008, doi: 10.1186/1743-8462-5-16.

[12] R. Fitriana et al., "Analisis Kebijakan Penataan Pedagang Kaki Lima," GOVERNANSI, vol. 6, no. 2, pp. 93-103, 2020.

[13] L. hasan Ashari, W. Lestari, and T. Hidayah, "Instrumen Penilaian Unjuk Kerja Siswa Smp Kelas Viii Dengan Model Peer Asssessment Berbasis Android Pada Pembelajaran Penjasorkes Dalam Permainan Bola Voli," J. Res. Educ. Res. Eval., vol. 5, no. 1, pp. 08-20, 2016, doi: 10.15294/jrer.v5i1.14876.

[14] Faridah and A. Rahman, "penggunaan Taman bungkul Sebagai Ruang Publik Dalam Mewujudkan Demokrasi Deliberatif (Studi Kasus terhadap Komunitas Senopati)," Kaji. Moral dan Kewarganegaraan, vol. 1, no. 1, pp. 116-132, 2013.

[15] A. Nurmandi and F. Muhammad, "Partisipasi Publik Deliberatif Berbasis Website Dalam Perumusan Kebijakan Daerah," Ilmu Pemerintah. dan Kebijak. Publik, vol. 2, no. 3, pp. 594-613, 2015.

[16] V. Tutui, "Democratic Deliberation Procedures: Theoretical and Practical Issues *," Argumentum-Journal Semin. Discursive Logic, Argumentation Theory, 2011. 